\title{
Evaluation of possibility to increasing sustainability of high-rise buildings through use university intellectual property
}

\author{
Igor Potekhin ${ }^{1, *}$, Valeryi Mischenko ${ }^{1}$, Angela Mottaeva ${ }^{2,3}$, Alexander Zheltenkov ${ }^{3}$ \\ ${ }^{1}$ Voronezh State Technical University, Moscow Avenue, 14, Voronezh, 394026, Russia \\ ${ }^{2}$ Moscow State University of Civil Engineering, Yaroslavskoe sh. 26, Moscow, 129337, Russia \\ ${ }^{3}$ Moscow Regional State University, 129125, Radio str. 10, Moscow, Russia
}

\begin{abstract}
In this article explained approach of valuation of intellectual property of Voronezh State Technical University, as her usefulness to increasing the sustainability and ecological safety of high-rise building. High-rise building is main type of buildings in modern cities. They include large volume of material mass, high volume of energy using and high volume of emissions. Using innovation solutions to improving ecology safety of high-rise buildings has large potential to city in whole. Explained in the article methods of calculation of effects helps to value sustainable solutions of present and future generations. Thus usefulness of patents express through usefulness regarding to high-rise building, including for sustainable development.
\end{abstract}

\section{Introduction}

The purpose of this section is defining method of patents evaluation. In case of uncertainty methodic of its evaluation, known of modern methodic. Supporting the development process for building products by the use of research portfolio analysis: A case study for wood plastics composite materials «Assuming that R\&D projects are based on an anticipated potential analysis, our study is the first to examine the use of project databases as an information pool about trends and future developments in WPC with respect to the construction industry. We derived from it a project-based future matrix by explaining current WPC developments in the light of the Technological S-Curveconcept to Foster (McKinsey). This method predicts whether a specific research area is still in the phase of generic research or already close to commercialisation. Findings are in the interest of the bio-plastics industry and particularly of the medium sized European WPC companies which will be enabled to easily gather significant input for their corporate innovation roadmap» [1].

«Although today's WPC research shows activities in both technical and ecological aspects, our portfolio did not undermine a potential trend in the combination of these, such as an eco-innovation approach. Obviously, manufacturers still focus on mechanical material and product properties rather than on ecologically driven sales arguments, i.e. cascading or

\footnotetext{
*Corresponding author: potekhin_300587@mail.ru
} 
sustainable disposal. Research in this field is solely driven by public institutions and is therefore in the generic state similar to green-composites but with orientation to applications»»

\section{Materials and Methods}

We will use matrix and patents of portfolio, but in our case we will seek direct benefit from patents, application to high-rise buildings and technological process of its construction.

Table 1. Patents of Voronezh state technical university

\begin{tabular}{|c|c|c|c|c|c|}
\hline \multirow{2}{*}{$\begin{array}{c}\text { Name of patent } \\
\text { Registration of patent }\end{array}$} & \multicolumn{5}{|c|}{ Technological result } \\
\hline & $\begin{array}{l}\text { Raw material } \\
\text { economy }\end{array}$ & $\begin{array}{l}\text { Energy } \\
\text { economy }\end{array}$ & $\begin{array}{c}\text { Decreasing } \\
\text { labor intensity }\end{array}$ & \begin{tabular}{|c|} 
Increasing \\
an accuracy
\end{tabular} & $\begin{array}{l}\text { Increasing } \\
\text { an ecology }\end{array}$ \\
\hline 1 & 2 & 3 & 4 & 5 & 6 \\
\hline $\begin{array}{l}\text { Raw material mix for making } \\
\text { construction products by non- } \\
\text { firing technology } \\
\text { RU } 2584018\end{array}$ & & + & & & + \\
\hline $\begin{array}{l}\text { Bearing support part of bridge } \\
\text { RU } 2547531\end{array}$ & & & & + & \\
\hline $\begin{array}{l}\text { Method of making coating of } \\
\text { sport playground } \\
\text { RU } 225094\end{array}$ & + & & & & + \\
\hline $\begin{array}{l}\text { Node joining of column with } \\
\text { monolithic concrete slab } \\
\text { RU } 2547035\end{array}$ & + & & + & + & \\
\hline $\begin{array}{l}\text { Nano-structure binder for } \\
\text { composite building materials } \\
\text { RU } 2408552\end{array}$ & + & & & + & \\
\hline $\begin{array}{l}\text { Method of manufacturing } \\
\text { composite organic-mineral } \\
\text { modificator of concrete } \\
\text { RU } 2454381\end{array}$ & + & & & & \\
\hline $\begin{array}{l}\text { Method of manufacturing foam } \\
\text { decoration } \\
\text { RU } 2276659\end{array}$ & + & & & & + \\
\hline $\begin{array}{l}\text { Firesafety intumescent material } \\
\text { RU } 2317274\end{array}$ & & & & & + \\
\hline $\begin{array}{l}\text { Combined pneumatic formwork } \\
\text { for making monolithic concrete } \\
\text { span structures } \\
\text { RU } 2478158 \\
\end{array}$ & + & & + & & \\
\hline $\begin{array}{l}\text { Unit for bio-cleaning of waste } \\
\text { sewage water } \\
\text { RU } 2114793\end{array}$ & & + & & & + \\
\hline $\begin{array}{l}\text { Method of manufacturing } \\
\text { hollow filler } \\
\text { RU } 2186047\end{array}$ & + & & & & + \\
\hline $\begin{array}{l}\text { High-regenerative level meter } \\
\text { RU } 2418270\end{array}$ & & & + & + & \\
\hline $\begin{array}{l}\text { High-frequency volume meter } \\
\text { RU } 2393434\end{array}$ & & & + & + & \\
\hline $\begin{array}{l}\text { Construction of road pavement } \\
\text { RU } 2340720\end{array}$ & & & & + & \\
\hline Polymer-concrete mix & & & + & + & \\
\hline
\end{tabular}




\begin{tabular}{|c|c|c|c|c|c|}
\hline RU 2394786 & & & & & \\
\hline $\begin{array}{l}\text { Composition for making } \\
\text { building material } \\
\text { RU } 2345968\end{array}$ & + & + & & & + \\
\hline $\begin{array}{l}\text { System of definition of } \\
\text { coordinates of underground } \\
\text { pipeline } \\
\text { RU } 2437127\end{array}$ & + & & & + & \\
\hline $\begin{array}{l}\text { Complex additive for concrete } \\
\text { mix } \\
\text { RU } 2443648\end{array}$ & & + & + & & \\
\hline $\begin{array}{l}\text { Sun heat collector } \\
\text { RU } 2444682\end{array}$ & & + & & & + \\
\hline $\begin{array}{l}\text { Accumulation heat exchanger } \\
\text { RU } 2333433\end{array}$ & + & + & & & \\
\hline $\begin{array}{l}\text { Sun shielding window } \\
\text { RU } 2327847\end{array}$ & + & + & & & \\
\hline $\begin{array}{l}\text { Grained filter } \\
\text { RU } 2116117\end{array}$ & + & & & & + \\
\hline $\begin{array}{l}\text { Sound absorbing cell panel } \\
\text { RU } 2206458\end{array}$ & & + & & & + \\
\hline $\begin{array}{l}\text { Compound blade of land grader } \\
\text { RU } 2498022\end{array}$ & + & & & + & \\
\hline $\begin{array}{l}\text { Vehicle power generator } \\
\text { RU } 2521742\end{array}$ & & + & & & \\
\hline $\begin{array}{l}\text { Stator of windpower unit } \\
\text { RU } 2517168\end{array}$ & & + & & & + \\
\hline $\begin{array}{l}\text { Rotor of windpower unit } \\
\text { RU } 2515577\end{array}$ & & + & & & + \\
\hline $\begin{array}{l}\text { Method of vibroshield of } \\
\text { mobile construction machines } \\
\text { RU } 2310781\end{array}$ & & & & + & + \\
\hline $\begin{array}{l}\text { Method of prevention of fatigue } \\
\text { crack on base of magnetodipole } \\
\text { RU } 2353909\end{array}$ & & + & & + & \\
\hline $\begin{array}{l}\text { System of automatic managing } \\
\text { of work tool of earthmoving } \\
\text { machine } \\
\text { RU } 2327010\end{array}$ & & + & & + & \\
\hline $\begin{array}{l}\text { Method of manufacturing } \\
\text { granite-cement products } \\
\text { RU } 2500655\end{array}$ & + & + & & & + \\
\hline $\begin{array}{l}\text { Noise silencer } \\
\text { RU } 2338964 \\
\end{array}$ & & & & & + \\
\hline
\end{tabular}

To evaluation usefulness the innovation of VSTU, we use definition High-rise building. A building is usually considered a "high-rise" if its height exceeds $23 \mathrm{~m}$ (75 ft) [2]. In this book is written about main types of structures and in weight mass of each structure.

In our case we choose more distributed structure for city building in Voronezh for building with 18 to 25 floors. This structure is made of reinforced concrete. Its weighted weight is: $32 \mathrm{~kg} / \mathrm{m} 2$ of rebar and $0,34 \mathrm{~m} 3 / \mathrm{m} 2$ of concrete [2]. 


\section{Modeling}

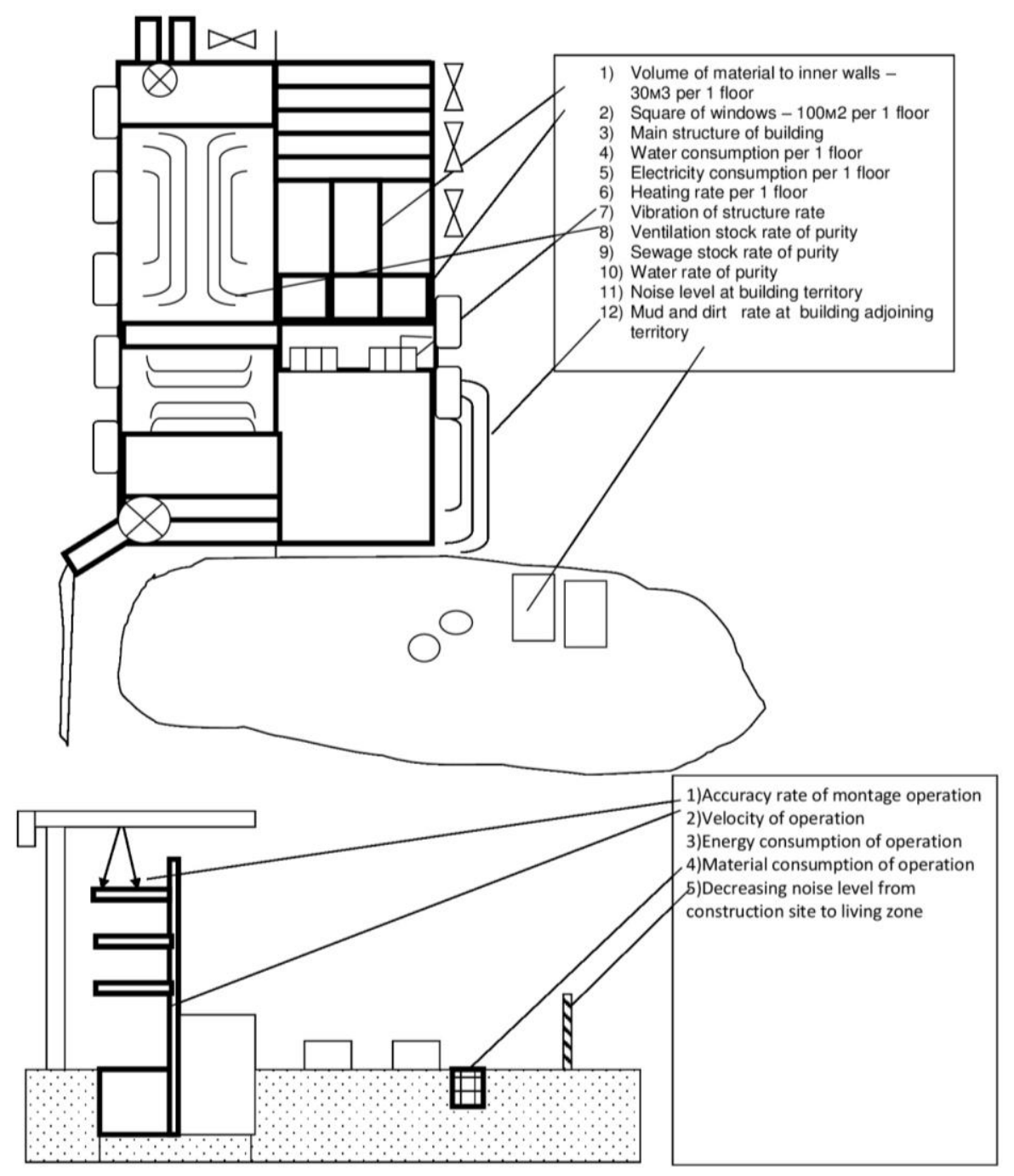

Fig. 1. Application of university patents at high-rise building construction structure and at site

Requirements to ecology and sustainability of city housing is written in the book «Reconstruction and renovation of current city housing».

«Development cities is accompanied with increasing a density of housing, especially in central heritage districts. By this is forgotten, that presenting open spaces improves temperature condition, insolation, aeration, giving conditions of dispersions of harmful exhausts in atmosphere, provide conditions to formulation ecological structure of settling. At present time, investors and city administration don't take into account these ecological criterions».

Developed measures of protection from noise include urban planning, architecture, construction activities - installation of shielding bands of forest plants and special fences, increasing sound insolation, using special noise protection screen-bariers between noise 
issues and objects, which need to be protected. System of water sewage have to take into account possibility of receiving drainage waters from different issues and common collectors. By technical possibility and coordination with nature protection administration, it could be use to feed garden plants by these sewage and drainage water through private pipeline.

Pathogenic zones could be technogenic or anthropogenic, which conditions is caused by industry impact, transport impact, power plants impact, garbage dumps, geochemical wastes. In this zones, the first system in human, which threated is nervous system - peoples feels irritability, headache, mood drop, fatigue [3].

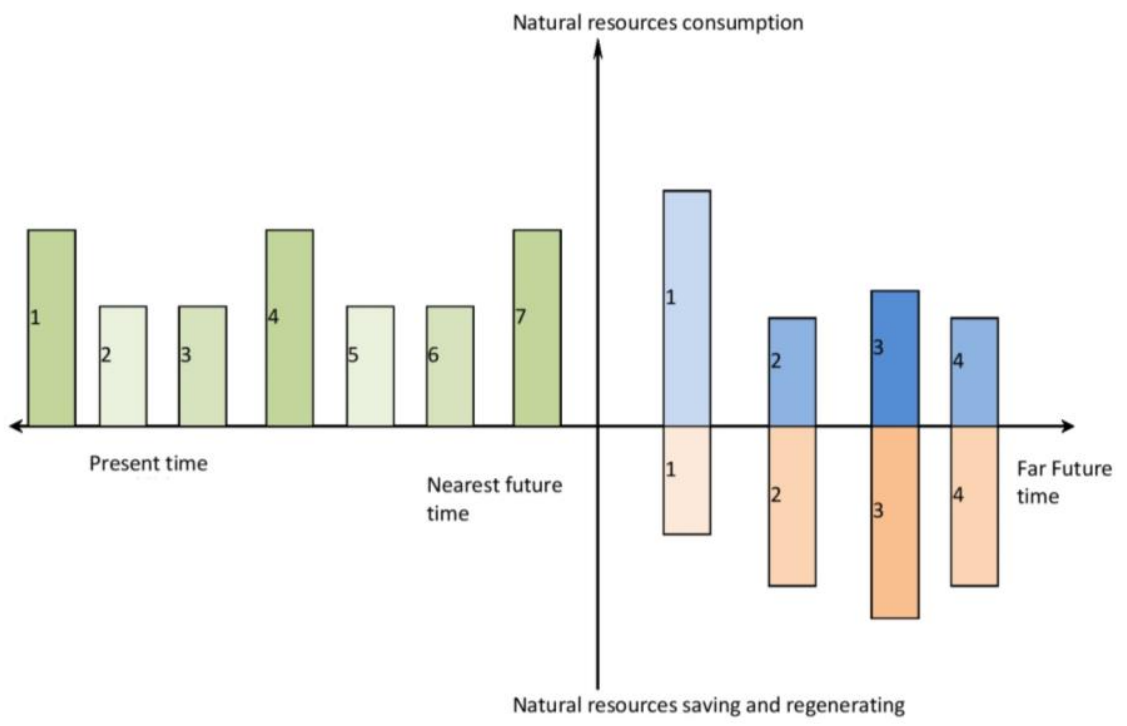

Fig. 2. Meaning of patents application at high-rise building to the sustainability of city

\section{Results}

Table 2. Explanation of sustainability of high-rise building

\begin{tabular}{|l|l|}
\hline \multicolumn{1}{|c|}{ Present time } & \multicolumn{1}{c|}{ Future time } \\
\hline 1.Usage of energy & 1.Economy of natural raw materials \\
\hline 2.Simplicity of building structure and construction & 2.Saving a biodiversity on building territory \\
\hline 3.Usage of raw materials & 3. Saving comfort for people on building territory \\
\hline 4.Payment only for natural raw resources & 4. New job specialties \\
\hline 5.Fee of building usage & \\
\hline 6.Clean around a building & \\
\hline 7.Pure exhaust from building & \\
\hline
\end{tabular}
building.

Our consideration of using some most meaningful patents to increasing sustainability of

Based on the plastic and hardened test results on of 14 types of concrete mixes, Mix 4 from Group M (360 kg total binder with, 80\% GGBFS, $0.35 \mathrm{w} / \mathrm{c}$ ) and Mix 14 from Group L $(300 \mathrm{~kg}, 60 \%$ GGBFS, $0.38 \mathrm{w} / \mathrm{c})$ are proposed for use in the construction of Masdar City in the UAE. These mixes meet the strength, durability, setting times, and workability requirements of Masdar City as well as they are cost effective compared to MC baseline mix. Although Mix 10 with 50\% GGBFS and 30\% FA achieved good durability and shrinkage performance as well as low carbon emissions it could not meet the workability requirements of Masdar City [4]. 
Production and transportation of many engineering construction materials requires high amounts of energy and has high levels of GHG (greenhouse gas) emissions associated with it. This can have a detrimental impact on the environment especially with the recent realization of the severity of climate change and global warming. Concrete is one of the most widely used construction materials and has $\mathrm{CO}_{2}$ emissions associated not just with the manufacturing process of cement, but also transport of ingredients over long distances. One of the solutions to reduce the environmental impact of concrete is to use more environmentally friendly ingredients and reduce the amount of transportation required in shipping these ingredients and/or the finished material. One of the building materials, Rammed Earth (RE) also known as "Pisé de terre" or simply "Pisé" (Anderson, 2000) is the material that Ecosol Design \& Construction (ED\&C) Ltd and the builder members of the North American Rammed Earth Builders Association (NAREBA) have been using for construction in North Western Washington State, USA; and Southern Alberta and British Columbia, Canada. The material typically used consists of locally available sand, soil, or gravel and is stabilized using nominal quantities of cement. The author was approached was approached by the Cement Association of Canada (CAC) to undertake a research project to study mechanical properties of RE. In the recent years, RE walls construction has become popular [5].

Natural sand has been the conventional fine aggregate in concrete production for many decades. However, there has been extensive research into alternative materials suitable to replace sand in concrete. The stress-strain curves (SSC) for concretes with quarry dust and river sand as fine aggregate showed similar behaviour. The SSCs for concrete with quarry dust showed higher maximum strains, $15 \%$ higher than those of conventional concrete. Based on the characteristics of the SSCs, it can be concluded that the structural design process of concrete with quarry dust within the elastic and inelastic range can be carried out normally without the need for modifications.

The modulus of elasticity of concrete with quarry dust was $8.6 \%$ lower than concrete with sand. However, concrete with $25 \%$ sand replacement gave the highest $7.9 \%$ higher than concrete with no sand replacement) modulus of elastic of concrete. The equations to predict modulus of elasticity of quarry dust concrete based on the compressive strength derived in this study varies greatly from those proposed in standard codes of practice [6].

This study investigates the first known application of light polyurethane foam (LPF) in construction of an extension to existing noise barriers. An experimental program was carried out to determine the LPF mechanical properties as well as the lateral resistance of the entire wall system. A fatigue test was also performed on a flexi-wall in order to evaluate its longterm performance under a repetitive loading. According to the results of this study, the following conclusions can be drawn:

The construction of a flexi-wall is significantly faster and more economic than the conventional method for the investigated application. The outcomes of the experiments showed that the structural performance of the wall for accelerated construction is completely acceptable. The mechanical performance of the flexi-wall is mainly governed by the steel rebars and as LPF is lighter and less expensive than cementitious material, a flexi-wall can be a good alternative to other types of extension for the investigated application.

Even though not examined in the current study, it is expected that applying a layer of shotcrete on the wall surfaces could enhance the flexural resistance, surface resistance and fatigue characteristics of the wall. Noise barriers or sound walls are usually constructed along the roadways to mitigate the airborne noise emanating from vehicles. Most of the provinces across Canada have established a "noise barrier retrofit program", which mainly involves the extension and renewal of the existing sound walls in urban environments, to mitigate noise pollution and minimize its impacts on public health.

In comparison with conventional masonry walls, a flexi-wall is more noise-absorbing and can be built significantly faster. The construction of flexi-walls along roadways is also 
less obstructive since there is no need for construction vehicles and mobile cranes, which usually block or constrict the roads during roadside construction. This accelerated technique also reduces traffic congestion, construction noise and risk of road accidents during the construction period which results in lower cost of the project [7].

It was proven that as the concrete compressive strength increases, the effect of the construction increases and causes more loss in the bending capacity of the structural element. A procedure to compensate for the reduction in the moment capacity due to the existence of a construction joint is presented [8].

There has been a drastic increase in the world population in recent years, new megacities are born and existing megacities become more populated. Besides new economical, managerial and social challenges associated with growing cities, a deformed energy budget pulls them toward a warmer climatic condition, known as urban heat island (UHI). Highly populated areas mandate cities to develop either vertically or horizontally, resulting in more released anthropogenic heat, a higher blockage effect against urban ventilation, a higher absorption of solar radiation due to the implementation of artificial materials, and eventually a reduced long-wave emission to sky due to the blockage effect of buildings. The UHI models are diverse in terms of scale with respect to the aim of a study, changing from building-scale for investigation of the impact of the UHI on thermal comfort of a pedestrian to urban-scale for exploring the effect of synoptic wind on urban ventilation.

Table 3. Cost valuation of non-financial effects of sustainable development, using a patents VSTU

\begin{tabular}{|c|c|c|c|c|}
\hline Effect & $\begin{array}{l}\text { Mechanism of } \\
\text { realization }\end{array}$ & $\begin{array}{l}\text { Recipient of } \\
\text { benefit }\end{array}$ & $\begin{array}{l}\text { Financial analog of } \\
\text { services }\end{array}$ & $\begin{array}{l}\text { Calculating } \\
\text { effect on } 1 \text { year }\end{array}$ \\
\hline $\begin{array}{l}\text { Economy of } \\
\text { nature } \\
\text { wealth } \\
\text { (mineral } \\
\text { deposits) }\end{array}$ & $\begin{array}{l}\text {-saving nature } \\
\text { deposits and } \\
\text { landscape } \\
\text {-decreasing } \\
\text { necessity in fossil } \\
\text { fuel consumption, } \\
\text { generation energy at } \\
\text { power station }\end{array}$ & $\begin{array}{l}\text {-majority of } \\
\text { city }\end{array}$ & $\begin{array}{l}\text { 1) decreasing fees for } \\
\text { garbage deposition } \\
\text { 2) decreasing fees for } \\
\text { energy consumption }\end{array}$ & $\begin{array}{l}\text { 1) } 100000 \text { RUB } \\
\text { 2) } 30000 \text { RUB }\end{array}$ \\
\hline \multirow[t]{2}{*}{$\begin{array}{l}\text { Saving a } \\
\text { biodiversity } \\
\text { at buildings } \\
\text { adjoining } \\
\text { territory }\end{array}$} & $\begin{array}{l}\text {-alive plants } \\
\text {-different kinds of } \\
\text { animals } \\
\text {-saving earth from } \\
\text { erosion }\end{array}$ & $\begin{array}{l}\text {-majority of } \\
\text { city } \\
\text {-buildings } \\
\text { owner }\end{array}$ & $\begin{array}{l}\text { 1) decreasing costs on } \\
\text { advertisment } \\
\text { 2) снижение расходов } \\
\text { на озеленение } \\
\text { территории } \\
\text { 2) decreasing costs on } \\
\text { gardening a territory }\end{array}$ & $\begin{array}{l}\text { 1) } 60000 \text { RUB } \\
\text { 2) } 40000 \text { RUB } \\
\text { 3) } 300000 \text { RUB } \\
\text { 4) } 30000 \text { RUB }\end{array}$ \\
\hline & Water quality & & $\begin{array}{l}\text { building } \\
\text { 3) increasing service } \\
\text { life of building } \\
\text { foundation } \\
\text { 4) decreasing costs on } \\
\text { water }\end{array}$ & \\
\hline $\begin{array}{l}\text { Saving } \\
\text { comfort } \\
\text { people } \\
\text { around a } \\
\text { building }\end{array}$ & $\begin{array}{l}\text {-clear air } \\
\text {-low noise } \\
\text {-clean }\end{array}$ & $\begin{array}{l}\text {-buildings } \\
\text { owner }\end{array}$ & $\begin{array}{l}\text { 1) decreasing costs on } \\
\text { advertising } \\
\text { 2) decreasing costs on } \\
\text { tiding up } \\
\text { 3) decreasing illness of } \\
\text { habitants }\end{array}$ & $\begin{array}{l}\text { 1) } 60000 \text { RUB. } \\
\text { 2) } 30000 \text { RUB. } \\
\text { 3) } 20000 \text { RUB. }\end{array}$ \\
\hline $\begin{array}{l}\text { New job } \\
\text { speciality }\end{array}$ & $\begin{array}{l}\text { Education new } \\
\text { skills and speciality }\end{array}$ & $\begin{array}{l}\text {-majority of } \\
\text { city } \\
\text {-buildings } \\
\text { owner } \\
\end{array}$ & $\begin{array}{l}\text { 1) dducating new } \\
\text { specialities }\end{array}$ & 1) 40000 RUB. \\
\hline
\end{tabular}




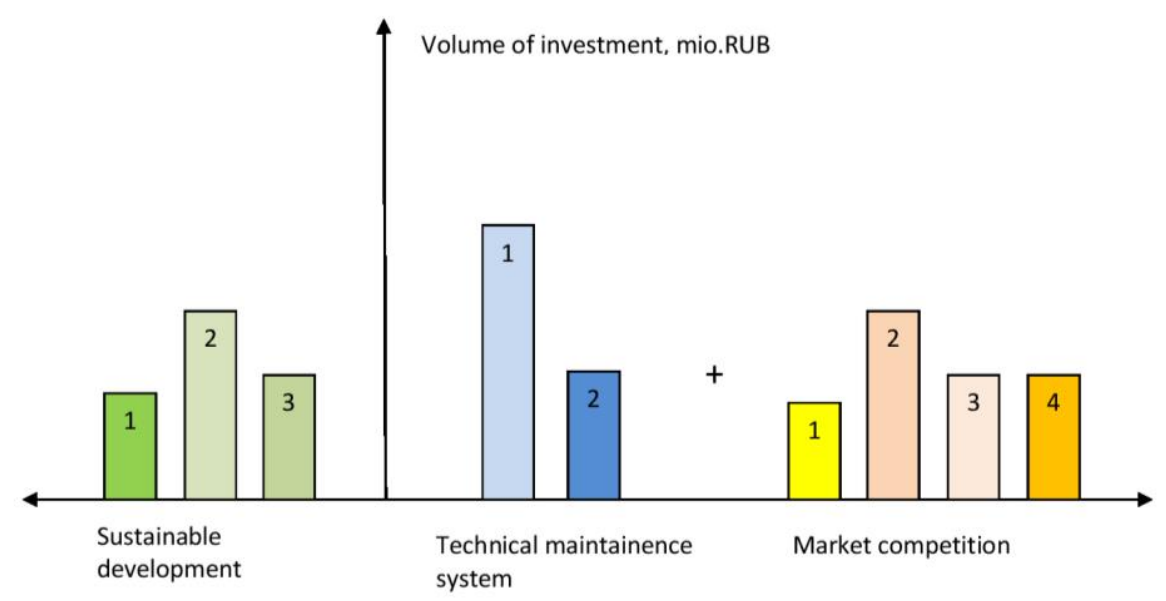

Fig. 3. Distribution of investments to development of construction company

Table 4. Explanation of distribution investments to development of construction company

\begin{tabular}{|l|l|l|}
\hline \multirow{2}{*}{$\begin{array}{l}\text { Investments in sustainable } \\
\text { development }\end{array}$} & \multicolumn{2}{|c|}{ Imperative investments } \\
\cline { 2 - 3 } & Technical maintainence system & \multicolumn{1}{c|}{ Market competition } \\
\hline 1. Prototype creation & 1.Renovation of equipment and tools & 1.Development new models \\
\hline $\begin{array}{l}\text { 2. Testing and modification of } \\
\text { prototype }\end{array}$ & 2.Repair of equipment & $\begin{array}{l}\text { 2.Purchase new equipment for } \\
\text { making a new models }\end{array}$ \\
\hline 3. Commercial production & & $\begin{array}{l}\text { 3.Testing and improving new } \\
\text { models }\end{array}$ \\
\hline & & $\begin{array}{l}\text { 4.Commercial production of new } \\
\text { models }\end{array}$ \\
\hline
\end{tabular}

\section{Conversation}

The influence on sustainable development of city with intellectual property of Voronezh State Technical University. The evaluation of useful potential of intellectual property. Modern requirements to ecological is regulated by LEED and BREAM, which most famous in the world. About the standards and another ecological sustainable construction is showed in book Kubba. Handbook of green building design and construction [9].

«Sustainable building materials also reduce landfill waste of which the $\mathrm{IgCC}$ codes mandate a minimum of $50 \%$ of construction waste must be diverted from landfills, and at least $55 \%$ of building materials must be salvaged, recycled-content, recyclable, biobased, or indigenous. The IgCC also mandates that buildings must be designed to span for a minimum of 60 years of life, and must show a service plan that justifies that. The following aspects should be considered when choosing building materials for a project:

- Choose sustainable construction materials and products whenever possible. Their sustainability can be measured by several characteristics such as recycled content, reusability, minimum off gassing of harmful chemicals, zero or low toxicity, durability, sustainably harvested materials, high recyclability, and local production. Use of such products promotes resource conservation and efficiency, minimizes the adverse impact on the environment and helps to harmonize with its surroundings.

- Employing dimensional planning and other material efficiency strategies reduce the amount of building materials needed and cut construction costs. For example, the design of rooms to 4-foot multiples minimizes waste by conforming to standard-sized wallboard and plywood sheets. 
- If possible, reuse and recycle construction and demolition materials. Using recycledcontent products also cuts costs and assists in the development of markets for recycled materials that are being diverted from landfills, an example of which is the use of inert demolition materials as a base course for a parking lot.

- Allocate adequate space to facilitate recycling collection and to incorporate a solid waste management program that reduces waste generation.

- Require waste management plans for managing materials through deconstruction, demolition, and construction.

Employing recycled/reused materials helps to ensure the sustainability of resources. If building projects use only virgin raw materials these materials will gradually be exhausted. As the availability of raw materials become scarce, prices will rise and before long the materials will no longer be obtainable.

This trend has already started to impact the availability of certain raw materials which are either no longer available or have become very scarce, and can only be obtained recycled from existing projects.

Improved technology is making it much easier and more cost-effective for designers and engineering professionals to incorporate sustainability into their high performance design strategies. Likewise, there are many recommended practices that can reduce the environmental and resource impacts of buildings, and enhance the health and satisfaction of their occupants. The most prominent strategies that come to mind include:

1. Using less to achieve more: The most effective green design solutions are able to address a number of needs with only a few elements. For example, a concrete floor may be simply finished with a colored sealant that reflects daylight for better illumination, and eliminates air pollutant emissions from floor coverings. The floor can also be used to store daytime heat and nighttime cold to provide occupant comfort. Thus a carefully designed element serves as structure, and finished surface, distributes daylight, and stores heat and cold, thus saving materials, energy resources, capital and operating costs.

2. Incorporate design flexibility and durability: Buildings that are designed with the flexibility to adapt to changing functions over long useful lives reduce life-cycle resource consumption. Durable sustainable structural elements that contain generous service space and are able to accommodate movable partitions can last for many decades, instead of being demolished because they are incapable of adapting to changing building functions. Durable envelope assemblies reduce life-cycle maintenance and energy costs and improve comfort.

3. To achieve maximum effectiveness combinations of design strategies must be carefully considered: Green buildings are incorporating increasingly complex systems of interacting and interrelated elements. Intelligent green design must consider the impact of these elements and systems on each other, and on the building as a whole. As an example, the need for mechanical and electrical systems is greatly affected by building form and envelope design. Combining strategies like daylighting, solar load control, and natural cooling and ventilation can all work together to reduce lighting, heating and cooling loads.

4. Take advantage of site conditions: Buildings are usually considered more sustainable when they respond to local microclimate, topography, vegetation and water resources; they are also usually more comfortable and efficient than conventional designs that rely on technological fixes and ignore their surroundings. As an example, Santa Monica in California has exemplary solar and wind resources for passive solar heating, natural cooling, ventilation and daylighting, but has meager local water supplies (some of which have recently been polluted). Taking advantage of such free natural resources, and conserving scarce high-priced commodities are appropriate approaches to reduce costs and connect occupants to their surroundings.

5. Adopt preventive maintenance, not repairing after the fact: Addressing potential problems from the beginning by applying preventive maintenance is both practical and 
economically prudent. For example, using low-toxicity building materials and installation practices is more effective than diluting indoor air pollution from toxic sources by employing large quantities of ventilation air.

Also it is necessary to take into account the involvement stakeholders and owners in ecological and sustainable investments.

What are motivations for stakeholder willingness to participate? For instance, it is found that perception of environmental risks and benefits influence willingness to participate and that stakeholders willingness to participation with effort, money and time differ with reference to whether a city region is new or already established. Willingness to participate was analysed by means of statistical analyses in Egypt, which seemed to vary across cities and neighbourhoods across the country, although it was concluded that action approaches were needed for stakeholder participation to facilitate dynamic transformation towards increased sustainable landscape. In order to identify motivations and barriers for collaboration between stakeholders in urban logistics in Singapore, a study showed that environmental benefits and risks influence motivations to participate. Barriers to stakeholder willingness in land use in Hong Kong include difficulties in urban renewal, inherent shortage of land, lengthy time involved in coordination and responsiveness to stakeholders, and overcomplicated administrative processes.

\section{Conclusion}

Urban areas account for $70 \%$ of carbon emissions, and are likely to be the locus of attention to reduce future emissions in developing countries. It is expected that, by 2030, about 2 gigatons $\mathrm{CO}_{2}$ eq of GHG emissions should be cut per annum in order to reach the $1.5^{\circ}$ level by 2050 (CAT, 2015). To make that happen, cities must take concrete steps towards defining and implementing various low-carbon projects and mitigation policies. Moving from business as usual (BAU) to a low carbon future requires an annual investment of between US\$4.5 and 5.4 trillion globally (CCFLA, 2015).

For instance, Asian Development Bank (ADB) places greater attention on financing projects that offer an array of GHG mitigations, energy efficiency, reduced accidents and other social engagement potentials.

An illustrative comparison between the market and nonmarket benefits of low-carbon investment projects in Nairobi, Colombo and Balikpapan. The vertical axis denotes the overall nonmarket benefits in millions of US dollars and horizontal axis represents the projects' market return. This diagram shows four different situations on which low-carbon investments can be judged:

(1)Win-win: This will happen when both of the market and nonmarket NPVs are above zero. This creates a desirable situation for both investors and the public to implement a lowcarbon project

(2)Win-lose: This occurs when a project offers large nonmarket benefits but the market benefits are negative (i.e., the project is financially infeasible). In this case, interventions may be required in case the project results in significant benefits to the society. This situation applies to all of the projects in this study.

(3)Lose-lose: This is when a project offers both negative nonmarket and market benefits. This is not desirable for either investors or the societies receiving the benefits of the investments.

(4)Lose-win: This is a scenario in which a project results in a positive market NPV but negative nonmarket NPV. In this case, project implementation needs to be avoided from a public policy perspective. 


\section{References}

1. N. Nagib, C. Gerges , A. Issa, S. Fawaz, Case Studies in Construction Materials, 5, 112123 (2016) https://doi.org/10.1016/j.cscm.2016.09.004

2. K. Rashidi, M. Stadelmann, A. Patt. Sustainable Cities and Society, 34, 69-78 (2017) https://doi.org/10.1016/j.scs.2017.06.003

3. K. Soma, M.W.C.Dijkshoorn-Dekker, N.B.P.Polman, Sustainable Cities and Society, 37, 438-450 (2018)

4. M. Elchalakani, T. Aly, E. Abu-Aisheh, Case Studies in Construction Materials, 1, 10-24 (2014) https://doi.org/10.1016/j.cscm.2013.11.001

5. R. Gupta, Case Studies in Construction Materials, 1, 60-68 (2014) https://doi.org/10.1016/j.cscm.2014.04.002

6. A. Rozhentsova, A. Mottaeva, MATEC Web of Conferences, 08076, DOI: https://doi.org/10.1051/matecconf/201710608076 (2017)

7. A. Mottaeva, IOP Conf. Series: Earth and Environmental Science, 90, 012120 doi:10.1088/1755-1315/90/1/0121209 (2017)

8. A. Pimenova, S. Kuzmina , N. Morozova, A. Mottaeva, MATEC Web of Conferences, 73, 07018 (2016) DOI: https://doi.org/10.1051/matecconf/20167307018

9. S. Kubba, Elsevier (2017) 